\title{
Content of anthocyanins of seed of Phaseolus vulgaris
}

\section{Contenido de antocianinas de la semilla de Phaseolus vulgaris}

\author{
MEX-ÁLVAREZ, Rafael Manuel de Jesús $\dagger^{*}$, GARMA-QUEN, Patricia Margarita, GUILLEN- \\ MORALES, María Magali and NOVELO-PÉREZ, María Isabel
}

Universidad Autónoma de Campeche, Faculty of Chemical Biological Sciences, Campeche, Mexico.

ID $1^{\text {st }}$ Author: Rafael Manuel de Jesús, Mex-Morales

ID $1^{\text {st }}$ Co-author: Patricia Margarita, Garma-Quen

ID $2^{\text {nd }}$ Co-author: María Magali, Guillen-Morales

ID $3^{\text {rd }}$ Co-author: María Isabel, Novelo-Pérez

DOI: $10.35429 / J E S N .2021 .20 .7 .7 .12$

Received: July 15, 2021; Accepted December 30, 2021

\begin{abstract}
The common bean (Phaseolus vulgaris $\mathrm{L}$ ) is an important food in Mexico that provides both macronutrients and bioactive substances that are beneficial for the health of its consumers, in particular it provides polyphenolic compounds such as anthocyanins that make it a functional food; the objective of the present work was to evaluate the content of polyphenols and their ferric iron reducing activity of beans grown in the Municipality of Hopelchen, Campeche (Mexico) to characterize their agronomic and alimentary value. The morphometric parameters of length, width, thickness, weight and volume were measured; An aqueous maceration of the bean seeds was carried out in an acid medium $(0.1 \mathrm{M} \mathrm{HCl})$ and the content of polyphenols (Folin Ciocalteu Method), anthocyanins (visible spectrophotometry) and determination of the Reducing Iron Power (FRAP, by the method of TPTZ) of the aqueous extracts. It was found that the concentration of anthocyanins correlates with the total content of polyphenols and with the reducing activity of the ferric ion, the aqueous extracts obtained had a content of total phenols of $413 \mathrm{mg}$ EAG/100g of seed, of anthocyanins of $42 \mathrm{mg}$ MGE/100 $\mathrm{g}$ of seed and an iron reducing power of 10.26 mol of $\mathrm{Fe}^{2+} / \mathrm{g}$ of seed. The morphometric characteristics and the polyphenol content of the Hopelchén bean demonstrate that the harvested grain is of good quality and corresponds to the expected values for this food.
\end{abstract}

Functional food, Bean episperm, Phytotherapy, Polyphenols

\begin{abstract}
Resumen
El frijol común (Phaseolus vulgaris L) es un alimento importante en México que aporta tanto macronutrientes como sustancias bioactivas que son benéficias para la salud de sus consumidores, en particular aporta compuestos polifenólicos como las antocianinas que lo configuran como un alimento funcional; el objetivo del presente trabajo fue evaluar el contendio de polifenoles y su actividad reductora de hierro férrico del frijol cultivado en el Municipio de Hopelchén, Campeche (México) para caracterizar su valor agronómico y alimentario. Se realizó una maceración acuosa de las semillas de frijol en medio ácido $(\mathrm{HCl} 0.1 \mathrm{M})$ y se determinó el contenido de polifenoles (Método de Folin Ciocalteu), antocianinas (espectrofotometría visible) y determinación del Poder Reductor de Hierro (FRAP, por el método de TPTZ) de los extractos acuosos. Se encontró que la concentración de antocianinas se correlaciona con el contenido total de polifenoles y con la actividad reductora del ión férrico, los extractos acuosos obtenidos presentaban un contenido de fenoles totales de $413 \mathrm{mg}$ EAG/100 g de semilla, de antocianinas de $42 \mathrm{mg}$ MGE/100 g de semilla y un poder reductor de hierro de $10.26 \mathrm{~mol} \mathrm{de} \mathrm{Fe}^{2+} / \mathrm{g}$ de semilla. El contenido de polifenoles del frijol de Hopelchén demuestra que el grano cosechado es de buena calidad y corresponde a los valores esperados para este alimento.
\end{abstract}

Alimento funcional, Episperma de frijol, Fitoterapia, Polifenoles

Citation: MEX-ÁLVAREZ, Rafael Manuel de Jesús, GARMA-QUEN, Patricia Margarita, GUILLEN-MORALES, María Magali and NOVELO-PÉREZ, María Isabel. Content of anthocyanins of seed of Phaseolus vulgaris. Journal of Environmental Sciences and Natural Resources. 2021. 7-20:7-12.

\footnotetext{
* Correspondence of the Author (E-mail: rafammex@uacam.mx)

$\uparrow$ Researcher contributing first author.
} 


\section{Introduction}

The common bean (Phaseolus vulgaris L.) is an essential part of the Mesoamerican diet; Currently it is sown in traditional and modern production systems that lead to morphological, physiological and genetic changes in this crop; Beans are important as a nutritional element because they provide macro and micronutrients of interest for health and are a good source of macronutrients (protein and carbohydrates) and provide vitamins and minerals in relatively adequate amounts (Hoc et al., 2002. Camacho et al., 2007 Hernández-López et al., 2013. PuertasMejía et al., 2013. Lams et al., 2021).

The bean testa has various components to which antioxidant properties are attributed, in this group of secondary metabolites the polyphenolic compounds stand out, particularly anthocyanins, flavonoids and tannins that play an important role in the prevention and treatment of certain diseases. (Iniestra et al., 2005. Camacho et al., 2007. Puertas et al., 2016. SánchezToledano et al., 2021).

Anthocyanins are very soluble in water and have bright colors, have an antioxidant activity that inhibits free radicals, preventing diseases such as cancer, atherosclerosis and inflammation, and they are also valued for their coloring power; For this reason, it is assumed that the bean contributes synergistically with its medicinal properties as an antioxidant, diuretic, anti-inflammatory, antitumor and antimicrobial and with a possible positive effect against some chronic diseases (Salinas-Moreno et al., 2005. Camacho et al., 2007. Puertas-Mejía et al., 2013).

However, information on the agronomic and food value of the common bean is scarce and scattered, despite its great ecological and economic importance. For this reason, there is a need to know the variation and phytochemical diversity of beans to define strategies for the rescue, conservation and use of native populations; since the macro and micronutrient content, in particular the anthocyanin concentration, varies according to the cultivation conditions and the sowing location (Cruz et al., 2009. Celis-Velázquez et al., 2010. HernándezLópez et al., 2013 Barrios et al., 2014. Casasola et al., 2021).
The present investigation was carried out with the objective of knowing the anthocyanin concentration of common bean seeds collected in the Municipality of Hopelchén of the State of Campeche, in the Mexican southeast.

\section{Methodology}

Bean lots collected in the Hopelchén region, Campeche State (Mexico) were used; the seeds obtained were dried at room temperature and stored in plastic containers for approximately three months at $4{ }^{\circ} \mathrm{C}$; for subsequent chemical analysis. The aqueous extracts of beans were obtained by static maceration, for this, $10 \mathrm{~g}$ of seed were deposited in $250 \mathrm{~mL}$ beakers and 100 $\mathrm{mL}$ of sterile distilled water was added, at intervals of $1,2,3,4,5,6$. At 7 and 8 h, aliquots of the supernatant were taken for the determination of total polyphenolic compounds by the Folin Ciocalteu method. The technique was carried out as follows: $100 \mu \mathrm{L}$ of the extract was added to $500 \mu \mathrm{L}$ of water in a test tube and then $100 \mu \mathrm{L}$ of the Folin-Ciocalteu reagent was added, it was left to react for 30 minutes and later $500 \square \mathrm{L}$ of $\mathrm{Na} 2 \mathrm{CO} 3$ was added. $20 \%$, incubated at room temperature for $30 \mathrm{~min}$. Finally, it was read in a spectrophotometer at $760 \mathrm{~nm}$. A calibration curve was made with gallic acid to determine the concentration of polyphenols present in each extract.

For the quantification of anthocyanins, the absorption spectrum of anthocyanins from beans was first obtained in a Lambda XLS + ${ }^{\circledR}$ spectrophotometer; Subsequently, the anthocyanins were extracted with $0.1 \mathrm{M} \mathrm{HCl}$ for ten replications, for this the weight of the bean seeds $(1,2,3,5$ and 10 seeds) was recorded and they were deposited in conical tubes with a lid. to which $50 \mathrm{~mL}$ of the $\mathrm{HCl}$ solution was added, it was left to rest for 24 hours at room temperature and finally the solution was filtered to recover the supernatant. The absorbance of the acidic solution was measured at $540 \mathrm{~nm}$ and the anthocyanin concentration was estimated by the following formula:

Anthocyanins $\left(\frac{m g}{L}\right)=A_{540 \mathrm{~nm}} * 16.7$

Where $A_{540 \mathrm{~nm}}$ is the absorbance of the acidic solution at $540 \mathrm{~nm}$. 
Likewise, the acid extracts were determined antioxidant reducing power of the ferric ion (FRAP, for its acronym in English) using the reagent TPTZ (2,4,6-tripyridyl-Striazine); First, the FRAP reagent was prepared by mixing $25 \mathrm{~mL}$ of $300 \mathrm{mM}$ sodium acetate buffer, $2.5 \mathrm{~mL}$ of $10 \mathrm{mM}$ TPTZ (2,4,6-tripyridylS-triazine) solution and $2.5 \mathrm{~mL}$ of $20 \mathrm{mM}$ ferric chloride solution. Subsequently, $100 \mu \mathrm{L}$ of the bean extract was added to $1000 \mu \mathrm{L}$ of a freshly prepared solution of the FRAP reagent, it was mixed very well, it was left to react for 60 minutes and the ferrous-tripyridyltriazine complex $\left(\mathrm{Fe}^{2+}-\mathrm{TPTZ}\right)$, formed by the reduction of the ferric-tripyridyl triazine complex $\left(\mathrm{Fe}^{3+}-\right.$ TPTZ), at $590 \mathrm{~nm}$ in a spectrophotometer; A calibration curve was made with ferrous sulfate as a standard.

The statistical analysis of the data was carried out in Excel ${ }^{\circledR}$ and in the statistical software SPSS V25.0 ${ }^{\circledR}$ of each morphometric variable, search in the bean grains to describe the population [graphs of descriptive statistics, mean $(\mathrm{X})$, standard deviation (SD ), maximum value (Max.) and minimum value (Min.)], subsequently a correlation matrix was made between the morphometric parameters obtained and a linear correlation analysis to obtain the Pearson coefficient and the equation of the line. For the determination of total polyphenols and Ferric ion reducing antioxidant activity (FRAP), a calibration curve was made by a linear correlation analysis and determination of the equation of the line, from which the values of the test sample were estimated; results are reported as the mean \pm one standard deviation.

\section{Results and discussions}

Regarding the content of polyphenols in the bean seed, it is shown first, in Figure. 1, the kinetics of polyphenol extraction with pure water. A maximum of polyphenol extraction was reached at eight to $25^{\circ} \mathrm{C}$, it is known that the extraction of polyphenolic compounds from beans increases with increasing temperature and using solvents such as methanol as well as using techniques such as microwave or ultrasound assisted extraction; The chemical characterization of the polyphenol content is important because the different varieties of $P$. vulgaris significantly appreciate their functional properties, especially the antioxidant activity (Puertas-Mejía et al., 2013. Puertas et al., 2016).

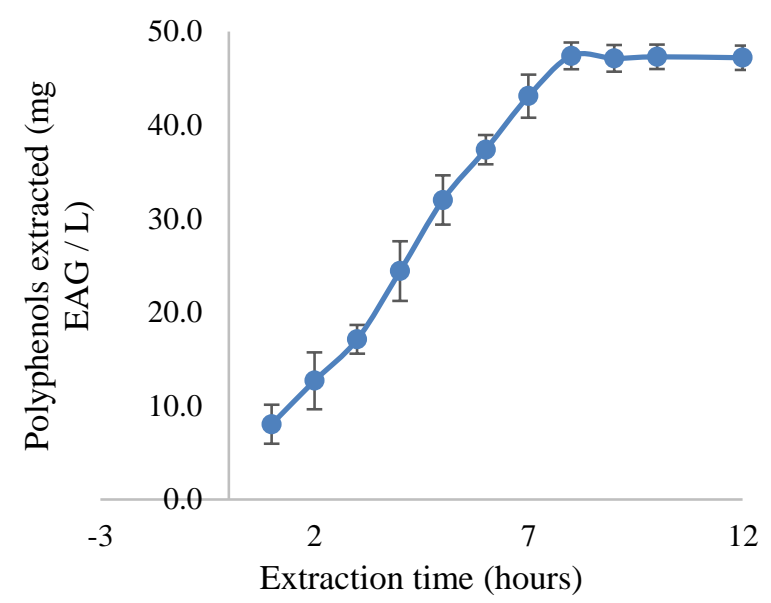

Figure 1 Kinetics of extraction of total polyphenols from bean seeds with distilled water $(\mathrm{n}=10)$

Source: Data obtained in the investigation

The content of total polyphenols and anthocyanins as well as the FRAP of the acidic aqueous extracts of the bean seed are reported in Table 1; the amount of total polyphenolic compounds extracted corresponds to the values reported for various bean varieties (Reynoso et al., 2007. Ombra et al., 2016. Puertas et al., 2016. Silva et al., 2018. Weidner et al., 2018). In the same way, the amount of anthocyanins determined in the bean samples analyzed coincide with those reported in the literature; Salinas-Moreno et al., (2005) determined that regardless of the racial origin, the black varieties had high contents of total anthocyanins in the whole grain with values between 37.7 and 71.6 $\mathrm{mg} / 100 \mathrm{~g}$; the content of polyphenols present in bean seeds depends on the geographic origin of the populations, environmental variations and genotype, so it is necessary to quantify the polyphenolic compounds in seeds of different varieties as this helps to determine which bean cultivars would provide the greatest benefits for its consumers (García-Díaz et al., 2016. Silva et al., 2018. Weidner et al., 2018).

\begin{tabular}{c|c|}
$\begin{array}{c}\text { Total } \\
\text { polyphenols } \\
\text { Antocianinas } \\
\text { FRAP }\end{array}$ & $413 \pm 28 \mathrm{mg} \mathrm{EAG} / 100 \mathrm{~g}$ of seed \\
\cline { 2 - 2 } & $42 \pm 3 \mathrm{EMG} / 100 \mathrm{~g}$ de semilla \\
\hline
\end{tabular}

Table 1. Polyphenol and anthocyanin content and ferric iron reducing activity of the acidic aqueous extracts of the Hopelchén bean seed. Results reported as $\mathrm{X} \pm \mathrm{SD}$, EAG $=$ gallic acid equivalent, $\mathrm{EMG}=$ malvidin glucoside equivalent, $\mathrm{n}=50$

Source: Data obtained in the investigation 
The concentration of anthocyanins extracted with $0.1 \mathrm{M} \mathrm{HCl}$ increased linearly and proportionally to the amount of bean seeds used in the maceration (Figure 2), this allows us to assume that the system was not saturated and that the amount of anthocyanins extracted was a function of the quantity of seeds as a limiting factor (Table 2); Likewise, it is observed that there was a greater extraction of anthocyanins when $\mathrm{HCl}$ was used compared to the neutral aqueous extracts; since anthocyanins are highly soluble substances in water that contain in their structure a pyryllium ring in an acid medium, they are found in the form of salts that increase their solibility and facilitate their extraction (Astrid, 2008. Puertas-Mejía et al., 2013).

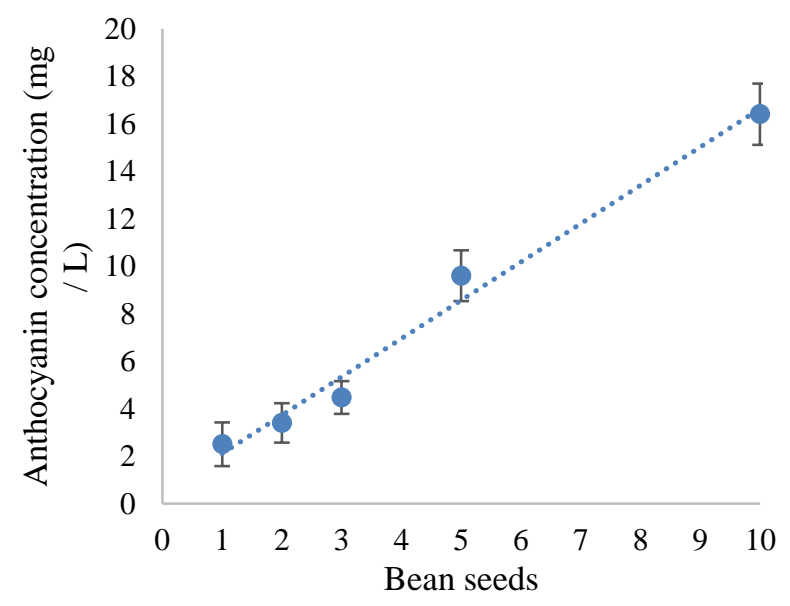

Figure 2 Anthocyanin concentration in $50 \mathrm{~mL} 0.1 \mathrm{M} \mathrm{HCl}$ extract with $1,2,3,5,10$ bean seeds $(n=10)$

\begin{tabular}{|r|r|}
\hline $\begin{array}{c}\text { Number of } \\
\text { seeds }\end{array}$ & \multicolumn{2}{c|}{$\begin{array}{c}\text { mg of Anthocyanins / 100 } \mathbf{g} \text { of } \\
\text { seeds }\end{array}$} \\
\hline 1 & $42.7 \pm 4.6$ \\
\hline 2 & $42.5 \pm 4.1$ \\
\hline 3 & $41.9 \pm 3.5$ \\
\hline 5 & $44.2 \pm 4.2$ \\
\hline 10 & $41.0 \pm 3.4$ \\
\hline
\end{tabular}

Table 2 Anthocyanin content extracted from bean seeds with $0.1 \mathrm{M} \mathrm{HCl}$. Results reported as $\mathrm{X} \pm \mathrm{SD}$, no significant differences are observed $(\mathrm{p}<0.05), \mathrm{n}=10$

Source: Data obtained in the investigation

With the values obtained by the determination of anthocyanins and the value of the FRAP, a correlation analysis was carried out that is shown in figure 3, it can be observed that the antioxidant activity (FRAP) is linearly correlated with the concentration of anthocyanins present in the extracts, that is, the anthocyanin content explains the antioxidant activity very well $\left(\mathrm{R}^{2}=0.9831\right)$.
This coincides with what is reported in the scientific literature that indicates that the therapeutic effects of anthocyanins are related to their antioxidant activity because they are effective to trap reactive oxygen species, inhibit lipoprotein oxidation and reduce metal ions (García-Díaz et al., 2016 Puertas et al., 2016. Weidner et al., 2018. Chí-Sánchez et al., 2021). One of the most used methods to determine the antioxidant activity of polyphenolic compounds is the FRAP; but it must be considered that in addition to polyphenols there are other compounds such as vitamins ( $\mathrm{C}$ and $\mathrm{E}$ ) and carotenoids that have antioxidant activity and may be present in extracts (Puertas et al., 2016. Silva et al., 2018. Weidner et al., 2018); in this case, the high correlation between FRAP and the amount of anthocyanins suggests that these are the main metabolites responsible for the antioxidant activity of the aqueous extracts of $P$. vulgaris.

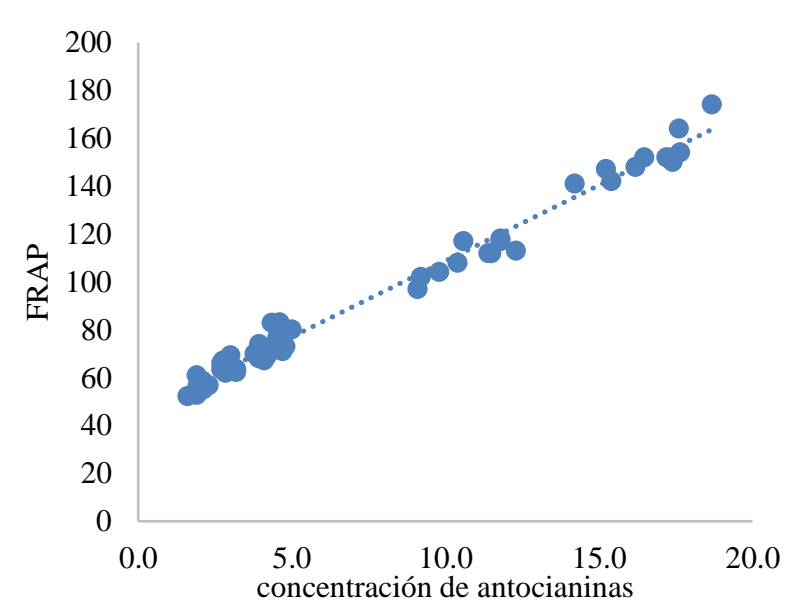

Figure 3 Correlation between anthocyanin concentration and FRAP

Source: Data obtained in the investigation

\section{Conclusions}

The morphometric characteristics and the polyphenol content of the beans from Hopelchén, Campeche (Mexico) show that the harvested grain is of good quality and corresponds to the expected values for this food; the antioxidant capacity of bean seeds correlates well with the amount of polyphenolic compounds, in particular with the anthocyanin content. 


\section{References}

Astrid Garzon, G. (2008). Las Antocianinas como colorantes naturales y compuestos bioactivos. Revisión. Acta biol. Colomb., 13 (3), $27-36$.

Barrios Gómez, E.J., López Castañeda, C., Kohashi Shibata, J., Acosta Gallegos, J.A., Miranda Colín, S., Mayek Pérez, N., y Canul Ku, J. (2014). Morfología del embrión en frijol y su comparación entre razas Durango y Jalisco. Revista mexicana de ciencias agrícolas, 5 (6), 965-978.

Camacho, R., Ríos-Ugalde, M., Pacheco, I., Acosta, J., Palomino, A., Ramos, M., González, E. y Guzmán, S. (2007). El consumo de frijol común (Phaseolus vulgaris L.) y su efecto sobre el cáncer de colon en ratas sprague-dawley. Agricultura técnica en México, 23 (1), 43-52.

Casasola Ojeda, D. E. (2021). Programa de fertilización para el cultivo del frijol (Phaseolus vulgaris L.) var. ICTA Chorti'ACM, con el nivel 50-60-100 Kg Ha-1 de NH4-P2O5-K2O, departamento de Chiquimula, Guatemal (Doctoral dissertation, Universidad de San Carlos de Guatemala, Centro Universitario de Oriente).

Celis-Velazquez, R., Peña-Valdivia, C.B., LunaCavazos, M., y Aguirre R., J.R. (2010). Caracterización morfológica de las semillas y consumo de reservas durante la emergencia de plántulas de frijol (Phaseolus vulgaris L.) silvestre y domesticado. Rev. Fac. Agron. (LUZ). 27, 61-87.

Chí-Sánchez, F. A., Alvarado-López, C. J., Cristóbal-Alejo, J., González-Moreno, A., \& Reyes- Ramírez, A. (2021). Contenido mineral de maíces criollos de Yucatán: análisis mediante $\mu$-Fluorescencia de Rayos X. Terra Latinoamericana, 39.

Cruz Balarezo, J., Camarena Mayta, F., Baudoin, J.P., Huaringa Joaquín, A., Blas Sevillano, R. (2009). Evaluación agromorfológica y caracterización molecular de la ñuña (Phaseolus vulgaris L.). Idesia (Arica), 27 (1), 29-40.
García-Díaz, Y.D., Aquino-Bolaños, E.N., Capistra-Carbarín A., y Chávez-Servia J.L. (2016). Cuantificación de compuestos fenólicos y actividad antioxidante en frijol. En: Compendio de Investigaciones Científicas en México. Centro de Investigaciones en óptica, pp: 105-113.

Hernández-López, V.M., Vargas-Vázquez, M.L.P., Muruaga-Martínez, J.S., HernándezDelgado, S., Mayek-Pérez, N. (2013). Origen, domesticación y diversificación del frijol común: Avances y perspectivas. Rev. fitotec. Mex, 36 (2), 95-104.

Hoc, P.S., Espert, S.M., Drewes, S.I., y Burghardt, A.D. (2002). Polimorfismo en Phaseolus vulgaris var. aborigineus (Fabaceae). Evidencias que indican hibridación natural. Rev. Biol. Trop., 51 (3), 725-736.

Iniestra González, J.J., Ibarra Pérez, F.J., Gallegos Infante, J.A.; Rocha Guzmán, N.E., y González Laredo, R, F. (2005). Factores antinutricios y actividad antioxidante en variedades mejoradas de frijol común (Phaseolus vulgaris). Agrociencia, 39 (6), 603-610.

Lamz Piedra, A., Cázares Chávez, Z., Jiménez Galindo, J. C., Molina Corral, F. J., Sepúlveda Ahumada, D. R., Rios-Velasco, C., \& Olivas Orozco, G. I. (2021). Traditional cooking with spices from Phaseolus vulgaris $\mathrm{L}$. and its antinutritional effect and bacterial inhibition. Biotecnia, 23(1), 62-69

Ombra, M.N., D'Acierno, A., Nazzaro, F., Riccardi, R., Spigno, P., Zaccardelli, M., Pane, C., Maione, M., y Fratianni, F. (2016). Phenolic Composition and Antioxidant and Antiproliferative Activities of the Extracts of Twelve Common Bean (Phaseolus vulgaris L.) Endemic Ecotypes of Southern Italy before and after Cooking. Oxidative Medicine and Cellular Longevity, 1-12.

Puertas Mejía, M.A., Mosquera-Mosquera, N., y Rojano, B. (2016). Estudio de la capacidad antioxidante in vitro de Phaseolus vulgaris $\mathrm{L}$. (frijol) mediante extracción asistida por microondas. Rev Cubana Plant Med, 21 (1), 4250 . 
Puertas-Mejía, M.A, Ríos-Yepes, Y., y Rojano, B.A. (2013). Determinación de antocianinas mediante extracción asistida por radiación de microondas en frijol (Phaseolus vulgaris L.) de alto consumo en Antioquia-Colombia. Revista Cubana de Plantas Medicinales, 18 (2), 288-297.

Reynoso Camacho, R., Ríos Ugalde, M.C., Torres Pacheco, I., Acosta Gallegos, J.A., Palomino Salinas, A.C., Ramos Gómez, M., González Jasso, E., y Guzmán Maldonado, S.H. (2007). El consumo de frijol común (Phaseolus vulgaris $\mathrm{L}$.) y su efecto sobre el cáncer de colon en ratas Sprague-Dawley. Agricultura técnica en México, 3(1), 43-52.

Salinas-Moreno, Y., Rojas-Herrera, L., SosaMontes, E., y Pérez-Herrera, P. (2005). Composición de Antocianinas en Variedades de Frijol Negro (Phaseolus vulgaris L.) Cultivadas en México. Agrociencia, 39 (4), 385-394.

Sánchez-Toledano, B., Cuevas-Reyes, V., CruzBravo, R., \& Zegbe, J. A. (2021). ACEPTACIÓN Y PREFERENCIA DE LOS CONSUMIDORES POR UN TALLARÍN ENRIQUECIDO CON HARINA DE COTILEDÓN DE FRIJOL.Revista Fitotecnia Mexicana, 44(1), 95-95.

Silva, M.O., Brigide, P., Toledo, N.M.V., y Canniatti-Brazaca, S.G. (2018). Phenolic compounds and antioxidant activity of two bean cultivars (Phaseolus vulgaris L.) submitted to cooking. Brazilian Journal of Food Technology, 21, e201607.

Weidner, S., Król, A., Karamac, M., y Amarowicz, R. (2018). Phenolic compounds and the antioxidant properties in seeds of green and yellow-podded bean (Phaseolus vulgaris L.) varieties. Journal of Food, 16, 1, 373-380. 